\title{
Biomass of thraustochytrid protoctists in coastal water
}

\author{
Hiroyuki Kimura, Tatsuhiro Fukuba, Takeshi Naganuma*
}

School of Biosphere Sciences, Hiroshima University, 1-4-4 Kagamiyama, Higashi-hiroshima 739-8528, Japan

\begin{abstract}
Abundance, cellular contents of carbon and nitrogen, and $\mathrm{C} / \mathrm{N}$ ratio of planktonic thraustochytrids in the Seto Inland Sea and the coastal Hyuga-nada, Japan, were determined. Thraustochytrid cells were stained with acriflavine and counted directly by epifluorescence microscopy. Thraustochytrids were found in the water column at a density of $2.5 \times 10^{3}$ to $4.5 \times 10^{4}$ cells $\mathrm{l}^{-1}$, with an overall average of $1.6 \times 10^{4}$ cells $\mathrm{l}^{-1}$. In order to estimate the impact of thraustochytrid biomass on the coastal plankton community, cellular carbon and nitrogen contents of a cultured thraustochytrid were determined. The carbon and nitrogen for $10 \mu \mathrm{m}$ cell contents were estimated to be $1.65 \times 10^{-4} \mu \mathrm{g} \mathrm{C}$ cell $^{-1}$ and $1.58 \times 10^{-5} \mu \mathrm{g} \mathrm{N}$ cell ${ }^{-1}$, respectively. The cellular $\mathrm{C} / \mathrm{N}$ ratio of 10.4 was higher than that known for pelagic bacteria. The estimated population biomass of thraustochytrids varied from 0.41 to $7.44 \mu \mathrm{g}$ $\mathrm{C} \mathrm{I}^{-1}$, with an overall average of $2.60 \mathrm{\mu g} \mathrm{C} \mathrm{I}^{-1}$; and 0.039 to $0.71 \mu \mathrm{g} \mathrm{N} \mathrm{I}^{-1}$, with an overall average of $0.23 \mu \mathrm{g} \mathrm{N} \mathrm{l}^{-1}$. The thraustochytrid carbon biomass corresponded to about 3.4 to $29 \%$ of total planktonic decomposers (bacteria and thraustochytrids). It is suggested that the contribution of thraustochytrids to the microbial food chain and carbon cycling through organic degradation and production may not be negligible.
\end{abstract}

KEY WORDS: Thraustochytrid $\cdot$ Fungoid protoctista $\cdot$ Abundance $\cdot$ Biomass $\cdot \mathrm{C} / \mathrm{N}$ ratio

\section{INTRODUCTION}

Thraustochytrids are a group of non-photosynthetic marine fungoid protoctists, characterized by the presence of an ectoplasmic net and a cell wall composed of non-cellulosic, sulfrylated scales (Darley et al. 1973). Thraustochytrids are classified in the phylum Heterokonta within the kingdom Chromista, and no longer regarded as a lower fungus. The phylum Heterokonta also includes numerous diatoms and brown algae as well as oomycetes (Cavalier-Smith et al. 1994).

Thraustochytrids are found in saline lakes as well as marine and estuarine waters, some being found in the oceanic water column (Schneider 1977, Moss 1986, Raghukumar et al. 1990). A rapid detection technique using the fluorogenic acriflavine dye was recently developed to count thraustochytrid cells directly. Acriflavine differentiates thraustochytrids from other pro-

\footnotetext{
'Addressee for correspondence.

E-mail: takn@ipc.hiroshima-u.ac.jp

toctists. Thraustochytrid cell walls and cell contents fluoresced red and bluegreen under blue excitation, while other protoctists fluoresced in different colors (Naganuma et al. 1998).

This fungoid protoctist is potentially important as an alternative food source and an enhancer of bacterial production in marine ecosystems (Naganuma et al. 1998). Thaustochytrids produce polyunsaturated fatty acids such as docosapentaenoic acid and docosahexaenoic acid (Nakahara et al. 1996), which may be an important food source for fish larvae. Furthermore, thraustochytrids may play a role in decomposing refractory organic substrates such as cell wall and phenolic compounds, and thus enhance the carbon cycle in coastal waters (Bremer 1995, Bremer \& Talbot 1995).

Previous studies have determined the abundance of thraustochytrids in the coastal Seto Inland Sea (Naganuma et al. 1998), the Arabian Sea (Raghukumar et al. 1990) and the North Sea (Schneider 1977). However, the biomass of thraustochytrids has not been estimated, because the cellular contents of carbon and nitrogen and $\mathrm{C} / \mathrm{N}$ ratio of thraustochytrids have not been determined. 
This study reports on (1) the abundance of thraustochytrids, (2) the determination of the carbon and nitrogen contents and $\mathrm{C} / \mathrm{N}$ ratio of the cultured thraustochytrid cell, and (3) biomass of natural thraustochytrids in the water column in the Seto Inland Sea, Japan, which is a eutrophicated semi-enclosed area that has attracted many ecological and environmental studies (Okaichi \& Yanagi 1997). This report presents the first determination of the cellular carbon and nitrogen contents of a cultured thraustochytrid and an estimation of population biomass of natural thraustochytrids in coastal waters.

\section{MATERIALS AND METHODS}

Sample collection and site description. Water samples were collected at 21 coastal sites (Table 1) in the Seto Inland Sea and the Hyuga-nada area, Japan, during cruises of the RV Toyoshiomaru, Hiroshima University, in June and July 1998 (Fig. 1). Samples were collected using Van Dorn bottles at 3 to 6 depths, 0 to $100 \mathrm{~m}$, depending on the water depths of the sampling

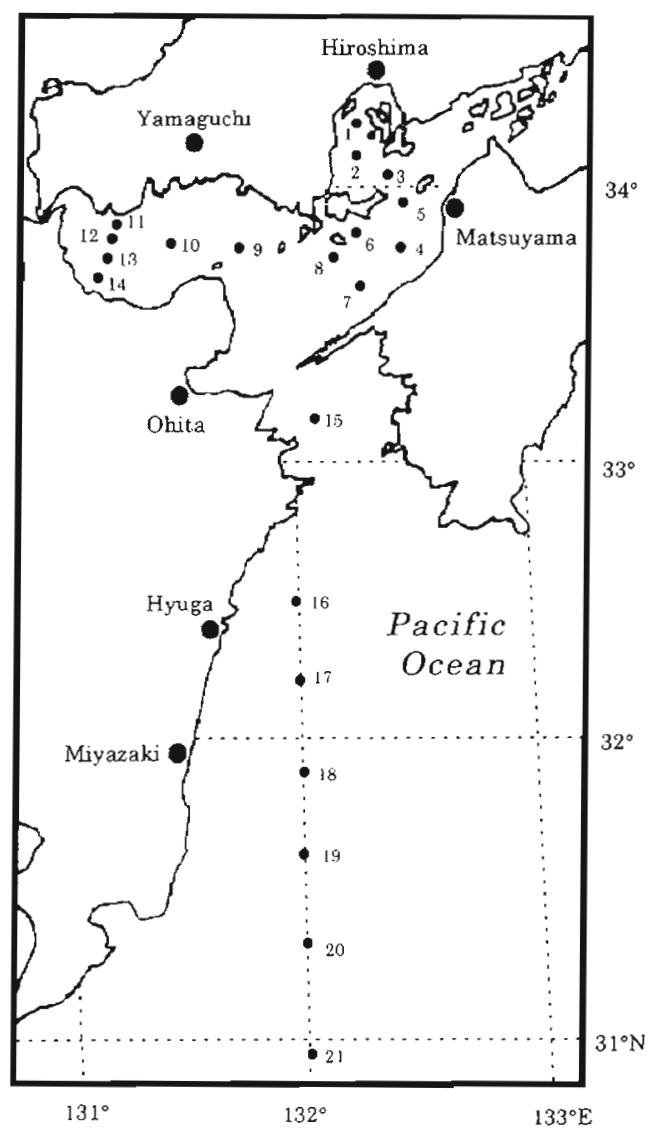

Fig. 1. Sites of sample collection in and near the Seto Inland Sea (Sites 1 to 14) and the Hyuga-nada (Sites 15 to 21), Japan
Table 1. Sites of sample collection and sea area names

\begin{tabular}{|lll|}
\hline Site & Sea area name & \\
\hline 1 to 3 & Hiroshima Bay & Seto Inland Sea \\
4 to 8 & Iyo-nada & Seto Inland Sea \\
9 to 14 & Suo-nada & Seto Inland Sea \\
15 & Uwakai & Outer Seto Inland Sea \\
16 to 21 & Hyuga-nada & Kuroshio"-affected \\
"Kuroshio Current, NW Pacific & \\
\hline
\end{tabular}

sites. The Van Dorn bottles were pre-washed and prerinsed with distilled water, and re-washed with seawater from the same site and depth immediately before sample collection.

Vertical profiles of water temperature, salinity, dissolved oxygen concentration and fluorescence intensity were monitored with a Sea Bird CTD al each sampling site. Water temperature ranged from 15.0 (Site $10,30 \mathrm{~m}$ ) to $27.4^{\circ} \mathrm{C}$ (Site $14,1 \mathrm{~m}$ ) among the sampling sites and depths. Salinity (psu) ranged from 30.89 (site $11,1 \mathrm{~m}$ ) to 34.85 (site $6,49 \mathrm{~m}$ ). Dissolved oxygen concentration was within the range of 2.62 (site $6,9 \mathrm{~m}$ ) to $4.48 \mathrm{mg} \mathrm{O}_{2} \mathrm{l}^{-1}$ (site $10,29 \mathrm{~m}$ )

Thraustochytrid and bacterial cell staining and counting. Thraustochytrid and bacterial cells were collected on pre-blackened polycarbonate filters (Isopore, Millipore; pore size $0.2 \mu \mathrm{m}$; diameter, $25 \mathrm{~mm}$ ) immediately after water collection. 10 to $20 \mathrm{ml}$ of sample water was filtered for collection of thraustochytrid cells, and 0.5 to $2 \mathrm{ml}$ was filtered for bacterial cell counts.

Thraustochytrid cells on filters were immediately stained with $4 \mathrm{ml}$ of the $0.2 \mu \mathrm{m}$-filtered $0.05 \%$ acriflavine (Sigma) in $0.1 \mathrm{M}$ citrate buffer at pH 3.0 (prepared from a $0.5 \%$ stock solution of acriflavine in distilled water) for $4 \mathrm{~min}$, and rinsed with the $0.2 \mu \mathrm{m}$ filtered $75 \%$ isopropanol for 1 min. (Raghukumar \& Schaumann 1993). Distilled water was used to prepare acriflavine and isopropanol solutions.

Bacterial cells on filters were stained with the $0.2 \mu \mathrm{m}$-filtered $0.01 \%$ acridine orange solution in $10 \mathrm{mM}$ phosphate buffer at pH 8.0 (Hobbie et al. 1977). The filters were air-dried and kept frozen at $-10^{\circ} \mathrm{C}$ unti. microscopic examination.

Thraustochytrid and bacterial cells were counted in 20 to 30 microscopic fields, and each count was duplicated. The stained cells were counted by epifluorescence microscopy with 420 to $490 \mathrm{~nm}$ violet-blue excitation. Acriflavine stained both the nuclear DNA and the cell wall sulfated polysaccharides, fluorescing green and red, respectively. Thraustochytrid cells fluoresced red and green, and thus were distinguished from other protoctists that fluoresce green only (Raghukumar \& Schaumann 1993) 
The limitation of the current staining technique is due to the fact that zoospores of most thraustochytrid species lack a cell wall (Moss 1986). Also, very small cells $(<5 \mu \mathrm{m})$ were not easily distinguishable, because the cell wall-associated red fluorescence was weaker than the nucleus-associated green fluorescence. Thus, the very small cells were not counted, and the counts reported in this study are probably underestimations.

Cultivation and molecular identification of a thraustochytrid isolate. A thraustochytrid strain was isolated during abalone (Haliotis discus discus) cell culture (Naganuma et al. 1996). Thraustochytrids are often found in abalone cell cultures and caused the demise of the molluscan cell cultures (Naganuma et al. 1994). The isolated strain was maintained in the laboratory with $0.98 \%$ sodium glutamate and $0.02 \%$ sodium inosinate in artificial seawater (Marine Art SF, Senju Seiyaku Co. Ltd, Osaka, Japan). Cultures of the strain were centrifuged at $10000 \times g$ for $15 \mathrm{~min}$. The cell pellet was lysed with Nal, and high molecular mass DNA was isolated from the lysate. DNA was purified with silica gel matrix using a DNA Purification Kit (TOYOBO, Osaka, Japan).

Partial 18S rDNA sequences of the thraustochytrid strain were amplified by the polymerase chain reaction ( $\mathrm{PCR}$ ) with 25 cycles of $96^{\circ} \mathrm{C}$ for $305,56^{\circ} \mathrm{C}$ for 1 min and $72^{\circ} \mathrm{C}$ for 1 min, using Taq DNA polymerase (Promega). The primer sequences for partial 18S IDNA amplification were 5'-AACCTGGTTGATCCTGCCAGT-3' (forward, 21mer) and 5' -TGATCCTTCTGCAGGTTCA $3^{\prime}$ (reverse, 19-mer) (Medlin et al. 1988). The size of the PCR products was about 1800 base pairs as expected. The PCR products were inserted into the plasmid, pCR 2.1TOPO, using the TOPO TA Cloning Kit (Invitrogen). The cloning of $18 \mathrm{~S}$ rDNA sequences from randomly selected recombinant Escherichia coli colonies were sequenced by the dideoxy cycle method using a model 373A DNA sequencer (Applied Biosystems, Inc.). Sequences of $18 \mathrm{~S}$ rDNA amplicons, designated HUBOL-1 and HUBOL-2, were analyzed for phylogenetics by the BLAST program (DNA Data Bank of Japan) and CLUSTAL W (Thompson et al. 1994).

Cellular $\mathrm{C}$ and $\mathrm{N}$ contents and $\mathrm{C} / \mathrm{N}$ ratio of a thraustochytrid strain. Cultured cells of the thraustochytrid strain were collected separately on pre-heated glass fiber filters (Whatman GF/F) and pre-blackened Isopore filters. The cells on the GF/F filters were rinsed with $3 \% \mathrm{NaCl}$ solution to remove residual organic materials and air- dried. The cells on the GF/F filters were used for determining carbon and nitrogen by a CHN analyzer (Model MT-5; Yanaco CO. Ltd Kyoto, Japan). Simultaneously, the cells on the Isopore filters were stained with acriflavine and counted by epifluorescence microscopy. The number and size (volume) of the cells were estimated during the microscopic observation. Thus, the $\mathrm{C}$ and $\mathrm{N}$ contents per cell, the factor for biovolume-to-biomass conversion, and the cellular $\mathrm{C} / \mathrm{N}$ ratio were calculated

\section{RESULTS AND DISCUSSION}

\section{Abundance of thraustochytrids and bacterioplankton}

The population density of planktonic thraustochytrids was within a range of $2.50 \times 10^{3}$ cells $l^{-1}$ (Site 21 ) to 4.52

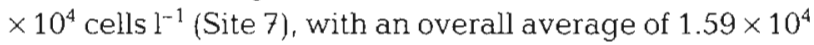
cells $\mathrm{l}^{-1}$. Population density of bacterioplankton ranged from $2.49 \times 10^{8}$ cells ${ }^{-1}$ (Site 17 ) to $2.25 \times 10^{9}{\text { cells }{ }^{-1}}^{-1}$

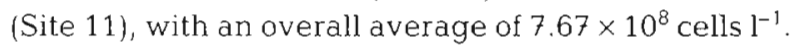
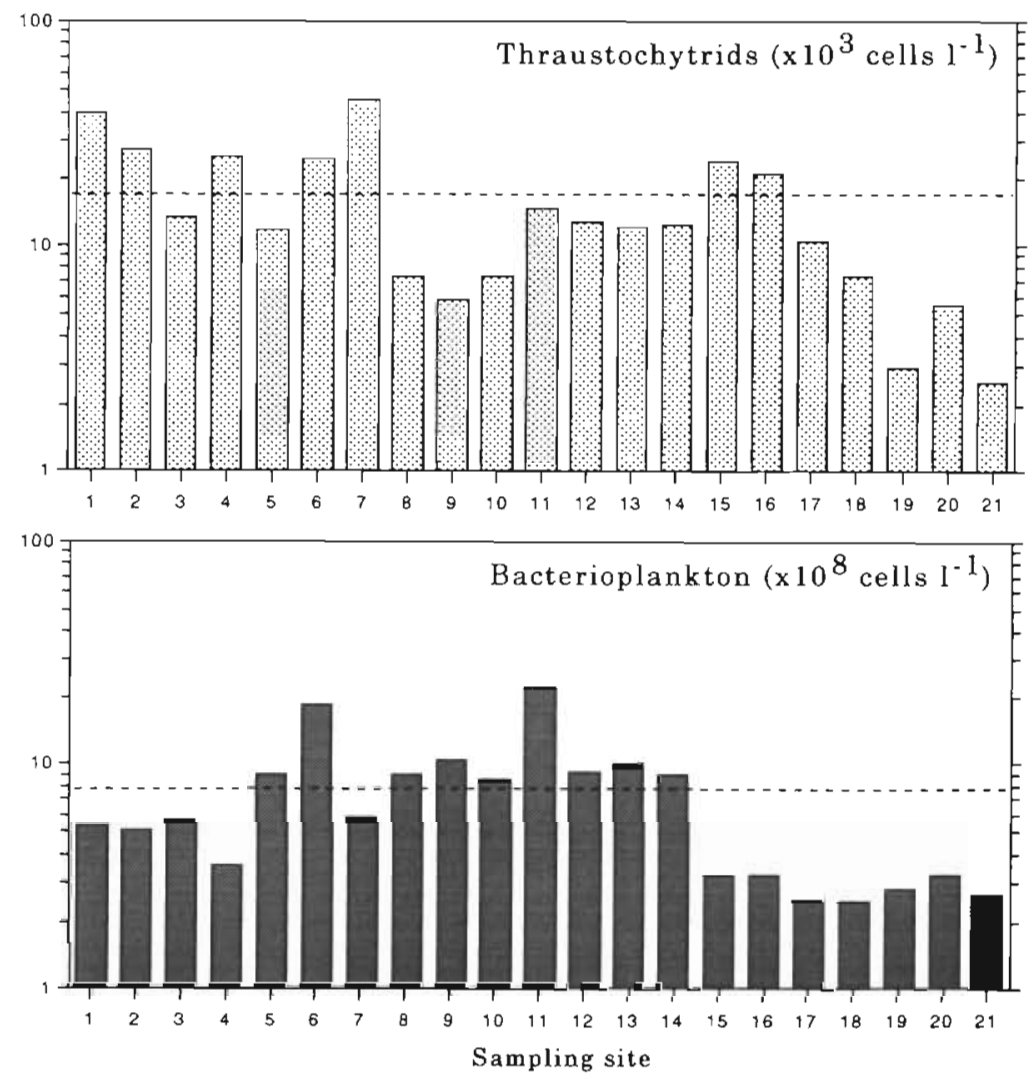

Fig. 2. Site-to-site variations in the abundances of planktonic bacteria thraustochytrids in the Seto Inland Sea and Hyuga-nada, Japan, in June and July 1998. Values are depth-weighted water-column averages. Broken lines indicate the overall averages 
Previous studies using direct enumeration reported thraustochytrid abundance of $1.0 \times 10^{4}$ cells $l^{-1}$ in the coastal Seto Inland Sea (Naganuma et al. 1998), a number equivalent to that found in the present study. Furthermore, the other studies reported thaustochytrid abundance of up to $1.1 \times 10^{3}$ cells $1^{-1}$ in the coastal Arabian Sea (Raghukumar et al. 1990) and to $1.5 \times 10^{3}$ cells $\mathrm{l}^{-1}$ in coastal North Sea waters, counted as infectious entities (Schneider 1977). The abundances in these earlier studies were lower than the abundance in this study. However, these earlier counts were based on cultivation, so comparisons cannot be made with the data obtained in this study.

Site-to-site variations of thraustochytrids and bacterioplankton abundance were observed (Fig. 2). Higher numbers of thraustochytrids occurred at sites closer to the coast. The abundance of thraustochytrids above the overall average was observed at the sites in Hiroshima Bay (Sites 1 and 2), Iyo-nada (Sites 4, 6 and 7) and Uwakai area (Site 15). The abundance of thraustochytrids under the overall average was observed at the sites in Suo-nada (Sites 9 to 14) and gradually decreased at Sites 15 to 21, with distance from the Seto Inland Sea. This is perhaps because Hiroshima Bay and Iyo-nada are highly eutrophicated, mainly by riverine input (Okaichi \& Yanagi 1997), but Suo-nada and the outer Seto Inland Sea receive little riverine input from the nearby coast. The Uwakai area (Site 15) is rather stagnant (Yanagi \& Yamamoto 1993) and receives a large amount of organic input associated with fish aquaculture and pearl oyster culture. The Uwakai area (Site 15) may possibly serve as an incubator for thraustochytrids. It is likely that planktonic thraustochytrids grow on refractory substrates of terrestrial origin, such as cellulose and lignin (Bremer 1995; Bremer \& Talbot 1995; Valiela 1995). Thus, thraustochytrid abundance is suggested to be influenced by riverine input of terrestrial organic matter.

In contrast, the abundance of bacterioplankton above the overall average was found at sites in Iyo-nada (Sites 5 and 6) and Suo-nada (Sites 11 to 14). High density of bacterioplankton was previously reported in Suo-nada (Tada et al. 1998), where river inflows are not significantly large. Instead, Suo-nada has high concentrations of seasonal and temporal chlorophyll a (Naganuma \& Miura 1997). On the other hand, abundance below the overall average was shown in Hiroshima Bay (Sites 1 to 4 ) where river inflow is significant, and in the outer Seto Inland Sea (Sites 15 to 21). Thus, it is suggested that bacterioplankton abundance is not necessarily river-associated, but rather affected by allochthonous organic production associated with chlorophyll $a$. This is in marked contrast to the presumed association of riverine organics and thraustochytrids.

\section{Depth-to-depth variation of abundance}

Depth-to-depth variation of thraustochytrid abundance (Fig. 3) was found in the water columns at population densities ranging from $0.104 \times 10^{3}$ cells $1^{-1}$ (Site 21 , $100 \mathrm{~m}$ ) to $104.3 \times 10^{3}$ cells $1^{-1}$ (Site $7,0 \mathrm{~m}$ ). Smaller variation of the bacterioplankton abundance (Fig. 3) was shown to range
Fig. 3. Depth-to-depth variations in vertical distribution of the abundances of planktonic bacteria and thraustochytrids in the Seto Inland Sea and the Hyuga-nada, Japan, in June and July 1998 
Table 2. Coefficients for the correlations among abundance of thraustochytrid (thra), bacterioplankton (bact) and depth. $(n=93)$

\begin{tabular}{|ccc|}
\hline & Thra vs depth & Bact vs depth \\
\hline Linear equation $(n=93)$ & 0.801 & 0.622 \\
Sites & & \\
$1(n=6)$ & 0.95 & 0.799 \\
$2(n=3)$ & 0.968 & 0.921 \\
$3(n=6)$ & 0.913 & 0.723 \\
$4(n=3)$ & 0.998 & 0.59 \\
$5(n=3)$ & 0.031 & 0.73 \\
$6(n=3)$ & 0.77 & 0.994 \\
$7(n=6)$ & 0.922 & 0.877 \\
$8(n=3)$ & 0.998 & 0.28 \\
$9(n=3)$ & 0.908 & 0.448 \\
$10(n=3)$ & 0.985 & 0.67 \\
$11(n=3)$ & 0.999 & 0.986 \\
$12(n=3)$ & 0.999 & 0.322 \\
$13(n=3)$ & 0.915 & 0.628 \\
$14(n=3)$ & 0.76 & 0.242 \\
$15(n=6)$ & 0.79 & 0.768 \\
$16(n=6)$ & 0.929 & 0.512 \\
$17(n=6)$ & 0.714 & 0.576 \\
$18(n=6)$ & 0.785 & 0.499 \\
$19(n=6)$ & 0.702 & 0.228 \\
$20(n=6)$ & 0.28 & 0.57 \\
$21(n=6)$ & 0.514 & 0.691 \\
& & \\
\hline
\end{tabular}

from $1.53 \times 10^{8}$ cells $^{-1}$ (Site $10,100 \mathrm{~m}$ ) to $29.3 \times 10^{8}$ cells $\mathrm{l}^{-1}$ (Site $6,0 \mathrm{~m}$ ). Generally, the abundance of thraustochytrids and bacterioplankton was high in the surface waters and decreased with an increase in depth.

The abundance of thraustochytrids and bacterioplankton was positively correlated to the sampling depths at each site (Table 2). The correlation coefficients were 0.801 for depth-thraustochytrids, and 0.622 for depth-bacterioplankton. This suggests that the abundance of thraustochytrids has greater depth control, probably linked to riverine organic input. The depth-to-thraustochytrids correlation was relatively low at Sites 5, 6, 14 and Sites 15 to 21 (outer Seto Inland Sea), where water mixing $\left(\log \left[\mathrm{H} / \mathrm{U}^{3}\right]>3.0\right)$ is presumed (Yanagi \& Okana 1993).

\section{S rDNA sequence of a cultured thraustochytrid}

The 18S rDNA-based analysis has been widely accepted in eukaryote taxonomy and phylogenetics, and a number of $18 \mathrm{~S}$ rRNA/DNA data has been integrated.

Two partial 18S rDNA sequences from the cultured thraustochytrid cells were determined in order to confirm that the 'thraustochytrid' culture used for $\mathrm{C} / \mathrm{N}$ determination was truly a thraustochytrid. The partial $18 \mathrm{~S}$ rDNA sequences were designated as HUBOL-1 (564 bp from the $5^{\prime}$-side) and HUBOL-2 (334 bp from the $3^{\prime}$-side), and registered in the DNA Data Bank of Japan (DDBJ; accession numbers, AB019134 and AB019135, respectively). Both HUBOL-1 and -2 were most closely related to the $18 \mathrm{~S}$ rDNA sequences of Ulkenia profunda (84-83\% matching), and to that of Thraustochytrium kinnei (83-82\% matching) in the Ribosomal Database Project (RDP; Maidak et al. 1994), all of which fell into the subclass Thraustochytridae (Cavalier-Smith et al. 1994). These sequences seem to be sufficient to place the cultured strain in the subclass Thraustochytridae. By designing taxon-specific DNA probes, it will be possible to identify and enumerate thraustochytrid cells in natural samples by epifluorescence microscopy and flowcytometry.

\section{Cellular $\mathrm{C}$ and $\mathrm{N}$ contents and $\mathrm{C} / \mathrm{N}$ ratio}

The cultured thraustochytrid was unicellular, globose to subglobose, and about $5 \mu \mathrm{m}$ in diameter. The cellular carbon and nitrogen contents were determined with an elemental (CHN) analyzer after collecting known numbers of the cells on GF/C filters. Thus, the values of $2.06 \times 10^{-5} \mu \mathrm{g}$ of $\mathrm{C}$ cell $^{-1}$ and $1.97 \times$ $10^{-6} \mu \mathrm{g}$ of $\mathrm{N}_{\text {cell }}{ }^{-1}$ were estimated for $5 \mu \mathrm{m}$ cells.

Observed diameters of natural thraustochytrid cells were 5 to $20 \mu \mathrm{m}$. Previous studies reported the diameter of particle-bound thraustochytrids ranges from 3.5 to $19.7 \mu \mathrm{m}$ (Raghukumar \& Schaumann 1993). Taking $10 \mu \mathrm{m}$ as an average diameter of the observed thraustochytrids (geometric average of 5 and $20 \mu \mathrm{m}$; $523 \mathrm{\mu m}^{3}$ ), values for carbon and nitrogen of a cultured thraustochytrids were calculated to be $1.65 \times 10^{-4} \mu \mathrm{g}$ of $\mathrm{C}$ cell ${ }^{-1}$ and $1.58 \times 10^{-5} \mu \mathrm{g}$ of $\mathrm{N}$ cell $^{-1}$. This estimate yielded a $\mathrm{C}$ density of $0.3 \mathrm{~g}$ of $\mathrm{C} \mathrm{cm}^{-3}$. Assuming the specific gravity of the thraustochytrid cell is 1 to 1.1 , the carbon-to-bodymass ratio is calculated as being 0.27 to 0.3 . This value is higher than that of bacteria (0.1), and implies a large impact in carbon cycling in the marine ecosystem.

The $\mathrm{C} / \mathrm{N}$ ratio of the cultured thraustochytrid cells was determined to be $10.5 \pm 1.1$, which was 1.5 to 1.8 times higher than that the ratio of oceanic $(6.8 \pm 1.2)$ and coastal (5.9 \pm 1.1 ) bacteria (Fukuda et al. 1998). Thus, it is suggested that thraustochytrids have higher carbon content than bacterioplankton assemblage with a greater influence on the carbon cycling in coastal waters than expected (Bremer 1995, Bremer \& Talbot 1995).

\section{Estimation of population biomass}

Estimated carbon and nitrogen contents of thraustochytrids ranged from 0.41 (Site 21) to $7.44 \mu \mathrm{g} \mathrm{C} \mathrm{l}^{-1}$ 
(Site 7), with an overall average of $2.60 \mu \mathrm{g} \mathrm{Cl}^{-1} ; 0.039$ (Site 21) to $0.71 \mathrm{\mu g} \mathrm{N}{ }^{-1}$ (Site 7), with an overall average of $0.23 \mu \mathrm{g} \mathrm{N}^{-1}$, respectively.

Based on cellular $\mathrm{C}$ and $\mathrm{N}$ contents of pelagic bacterioplankton of $30.2 \mathrm{fg}$ of $\mathrm{C}_{\text {cell }}^{-1}$ and $5.8 \mathrm{fg}$ of $\mathrm{N} \mathrm{cell}^{-1}$ (Fukuda et al. 1998), population biomass of bacterioplankton ranged from 7.53 (Site 18) to $68.1 \mu \mathrm{g} \mathrm{C} \mathrm{I} \mathrm{I}^{-1}$ (Site 11) with an average of $21.7 \mu \mathrm{g} \mathrm{Cl}^{-1}$, and from 1.44 (Site 18) to $13.0 \mathrm{\mu g} \mathrm{N} \mathrm{I}^{-1}$ (Site 18) with an overall average of $4.17 \mu \mathrm{g} \mathrm{N} \mathrm{^{-1 }}$

There was site-to-site variation of the thraustochytrids biomass ratio with carbon biomass (Fig. 4) in the planktonic decomposer community (planktonic bacteria and thraustochytrids). The ratio ranged from $3.4 \%$ (Site 9) to $29.7 \%$ (Site 7). Overall average $(14.0 \%)$ ratios were found in Hiroshima Bay (Sites 1 and 2), Iyo-nada (Sites 4, 5,6 and 7), and the Bungo Channel (Sites 15 and 16). This was probably due to riverine input of terrestrial organic matter which thraustochytrids may utilize. In contrast, high biomass ratio of bacterioplakton was high in Suo-nada (Sites 9 to 14 ), which receives fewer riverine inputs. Thus, it can be postulated that the significance of thraustochytrid biomass ratio largely depends on the riverine input of terrestrial organic materials. The influence of riverine input on thraustochytrid biomass ratio was also shown in the transect from Sites 15 to 21 . There was a general tendency for the biomass ratio of thraustochytrids to decrease with increased influence of open ocean (Kuroshio) water. On the other hand, the biomass ratio of bacterioplankton increased at the Kuroshio-affected sites, where allochthonous dissolved organic materials (DOM) are thought to be less abundant. In the low DOM waters, small-sized $\left(0.1 \mathrm{\mu m}^{3}\right)$ bacterioplankton, having a greater surface-to-volume ratio, are regarded as being more advantageous in DOM-uptake than large-sized $\left(>500 \mu \mathrm{m}^{3}\right)$ thraustochytrids.

\section{Ecological role of thraustochytrids}

Thraustochytrids have ectoplasmic nets which arise from organelle complexes, appearing as fenestrated, anastomosing rays (Perkins 1973). They are not used for motility, but contain extracellular enzymes that allow penetration of solid surfaces and breakdown of organic compounds for adsorption and transfer of nutrients (Bremer 1976, Coleman \& Vestal 1987). The presence of extensive ectoplasmic nets with highly degradative enzymes indicates a primary role in decomposition (Fell \& Newell 1998). Previous studies reported that the nets and enzymes of thraustochytrids penetrate and digest the cellulosic cell wall of plants (Perkins 1973). Hence, they are thought to play an important ecological role in degrading refractory substrates such as plant cell wall materials (Bremer 1995, Bremer \& Talbot 1995 , Valiela 1995). This is one aspect of thraustochytrid contribution to microbial loop and carbon cycling

In addition, the nutritional value of thraustochytrid in the food web may be important. Thraustochytrids contain high levels of polyunsaturated fatty acids such as docosahexaenoic acid (DHA) and docosapentaenoic acid (Nakahara et al. 1996). These compounds often occur in marine animals. They are not synthesized de novo by animals, and have to be obtained as a diet from primary production including thraustochytrids (Fell \& Newell 1998). In particular, it would be
Fig. 4. Contribution (\%) of the thraustochytrid biomass to the planktonic decomposer populations (bacteria and thraustorhytrids). C- and N-based biomass were estimated for both populations 
presumed that thraustochytrids are an important alternative food source for fish larvae of species known to have a high concentration of DHA, such as sardine. This is another aspect of thraustochytrid contribution to the microbial loop and carbon cycling

Abundance and biovolume of natural planktonic thraustochytrids were previously reported (Schneider 1977, Raghukumar et al. 1990, Naganuma et al. 1998). Our study has estimated the biomass and $\mathrm{C} / \mathrm{N}$ ratio of thraustochytrids. Further work is needed to estimate thraustochytrid production in natural waters.

Acknowledgements. The author is grateful to the crew of the $T$ \& RV 'Toyoshio Maru', Hiroshima University for the onboard assistance. Prof. S. Uye, Hiroshima University, kindly offered the opportunity for sample collection during the 'Toyoshio Maru' cruises. We also thank Terumi Akeno, National Research Institute of Brewing, Japan, for the help in DNA sequencing, and Koji Ono, Hiroshima University, for measuring carbon and nitrogen contents.

\section{LITERATURE CITED}

Bremer GB (1976) The ecology of marine lower fungi. Recent Advances in Aquatic Mycology. Elek Science, London, p $313-331$

Bremer GB (1995) Lower marine fungi (Labyrinthulomycetes) and the decay of mangrove leaf litter. Hydrobiologia 295 89-95

Bremer GB, Talbot G (1995)Cellulolytic enzyme activity in the marine protist Schizochytrium aggregatum. Bot Mar 38: $37-41$

Cavalier-Smith T, Allsopp MTEP, Chao EE (1994) Thraustochytrids are chromists, not fungi: 18S r RNA signature of Heterokonta. Philos Trans R Soc Lond B Biol Sci 346 : $387-397$

Coleman NY, Vestal JR (1987) An epifluorescent microscopy study of enzymatic hydrolysis of fluorescein diacetate associated with the ectoplasmic net elements of the protist Thraustochytrium striatum. Can J Microbiol 33:841-843

Darley WM, Porter D, Fuller MS (1973) Cell wall composition and synthesis via Golgi-directed scale formation in the marine eukaryote Schizochytrium aggregatum, with a note on Thraustochytrium sp. Arch Mikrobiol 90:89-106

Fell JW, Newell SY (1998) Molecular approaches to the study of the ocean, Chapter 12. Chapman \& Hall Publishers, London, p 262-263

Fukuda R, Ogawa H, Nagata T, Koike I (1998) Direct determination of carbon and nitrogen contents of natural bacterial assemblages in marine environments. Appl Environ Microbiol 64:3352-3358

Hobbie JE, Daley RJ, Jasper S (1977) Use of Nuclepore filters for counting bacteria by fluorescence microscopy. Appl Environ Microbiol 33:1225-1228

Maidak BL, Larsen N, McCaughey MJ, Overbeek R, Olse GJ,
Fogel K, Blandy J, Woese CR (1994) The ribosomal database project. Nucleic Acids Res 22:3485-3487

Medlin L, Elwood HJ, Stickel S, Sogin ML (1988) The characterization of enzymatically amplified eukaryotic 16S-like rRNA-coding regions. Gene 71:491-499

Moss ST (1986) Biology and phylogeny of the Labyrinthuales and Thraustochytoriales. In: Moss ST (ed) The biology of marine fungi. Cambridge University Press, Cambridge, p $105-129$

Naganuma T, Miura S (1997) Abundance, production and viability of bacterioplankton in the Seto Inland Sea, Japan J Oceanogr 53:435-442

Naganuma T, Degman BM, Horikoshi K, Morse DE (1994) Myogenesis in primary cell cultures from larvae of the abalone Haliotis rufescens. Mol Mar Biol Biotechnol 3:131-140

Naganuma T, Akutsu T, Ishida T, Kato C, Horikoshi K (1996) In situ RT-PCR from the b-tubulin mRNA in abalone cells in primary cultures. J Mar Biotechnol 4:75-81

Naganuma T, Takasugi $H$, Kimura $H$ (1998) Abundance of thraustochytrids in costal plankyon. Mar Ecol Prog Ser 162:105-110

Nakahara T, Yokochi T, Higashihara T, Tanaka S, Yaguchi T, Honda D (1996) Production of docosahexaenoic and docosapentaenoic acid by Schizochytrium sp. isolated from Yap Islands. JAOCS 73:1421-1426

Okaichi T, Yanagi T (eds) (1997) Sustainable development in the Seto Inland Sea, Japan. Terra Scientific Publishing Co, Tokyo

Perkins FO (1973) Observations of Thraustochytriaceous (Phycomycetes) and Labyrinthulid (Rhizopodea) ectoplastomic nets on natural and artificial Substrates - an electron microscope study. Can J Bot 51:485-92

Raghukumar S, Rahukumar C, Rajendran A (1990) Abundance of thraustochytrid fungi in the Arabian Sea. Estuar Coast Shelf Sci 31:351-358

Raghukumar S, Schaumann K (1993) An epifluorescence microscopy method for direct detection and enumeration of the fungi-like marine protists, the thraustochytrids. Limnol Oceanogr 38:182-187

Schneider J (1977) Fungi. In: Rheinheimer G (ed) Microbial ecology of a brackish water environment. Springer-Verlag, Berlin, p 90-102

Tada K, Monaka K, Morishita M, Hashimoto T (1998) Standing stocks and production rates of phytoplankton and abundunce of bacteria in the Seto Inland Sea, Japan. J Oceanogr 54:285-295

Thompson JD, Higgins DG, Gibson TJ (1994) CLASTAL W: Improving the sensitivity of progressive multiple sequence alignment through sequence weighing, position-specific gap penalties and weight matrix choice. Nucleic Acids Res 22:4673-4680

Valiela I (1995) Marine ecological processes, 2nd edn. Springer-Verlag, New York

Yanagi T, Okana S (1993) Tidal fronts in the Seto Inland Sea. In: Memoirs of the faculty of Engineering. Ehime University $12(4): 337-343$

Yanagi T, Yamamoto $T$ (1993) Data assimilation for prediction of coastal sea condiion. J Adv Mar Tech Conf 8:85-98

Submitted: April 4, 1999; Accepted: June 10, 1999 Proofs received from author(s): November 8,1999 